\title{
Ketogenic Ratio Determines Metabolic Effects of Macronutrients and Prevents Interpretive Bias
}

\author{
Tanya Zilberter ${ }^{1}$ and Yuri Zilberter ${ }^{2 \star}$ \\ ${ }^{1}$ Infotonic Consultancy, Marseille, France, ${ }^{2}$ Inserm UMR 1106, Marseille, France
}

Keywords: diet classification, ketogenic threshold, anti-ketogenic threshold, macronutrients, metabolic effects of diets

\section{INTRODUCTION}

OPEN ACCESS

Edited by:

Mary C. McKenna,

University of Maryland, Baltimore,

United States

Reviewed by:

Carl E. Stafstrom,

Johns Hopkins Medicine,

United States

Michelle A. Puchowicz,

Case Western Reserve University,

United States

*Correspondence:

Yuri Zilberter

zilberter@gmail.com

Specialty section:

This article was submitted to Neuroenergetics, Nutrition and Brain

Health,

a section of the journal

Frontiers in Nutrition

Received: 29 May 2018 Accepted: 07 August 2018

Published: 30 August 2018

Citation:

Zilberter T and Zilberter Y (2018) Ketogenic Ratio Determines Metabolic

Effects of Macronutrients and

Prevents Interpretive Bias.

Front. Nutr. 5:75.

doi: 10.3389/fnut.2018.00075
Thomas Seyfried remarked in his book [(1), page 6]: "The definition of ketogenic diet allows for considerable leeway in food choices as long as the individual has reduced blood glucose and is producing ketones." Unfortunately, these parameters are lacking in many if not most of studies into metabolic effects of macronutrients. Meanwhile, there is a precise way to predict whether or not a diet will induce ketosis and the aim of this opinion article is to advocate a broader usage of this way. Why is this so important?

Excess of carbohydrate intake typical for consumers of the Western diet may cause detrimental effects on metabolism and increase risks of the onset and progression of many neurodegenerative diseases (2-4). On the other hand, diets high in fat and low in carbohydrates decrease appetite, probabilities of food addiction and obesity, and are neuroprotective $(5,6)$. Carbohydrate restriction induces physiological changes which are very similar to the well documented beneficial effects of calorie restriction $(7,8)$. Conversely, the hallmark of high-carbohydrate diets is homeostatic inadequacy (9), an overproduction of reactive oxygen species and advanced glycation products, both of which are implicated in neuroinflammation and neurodegeneration (10-12). However, the meaning of "high" or "low" in diets' definition has been drifting away from the previously established quantitative criterion known as ketogenic ratio.

\section{THE KETOGENIC RATIO}

Almost a century ago, Woodyatt (13) wrote: "antiketogenesis is an effect due to certain products which occur in the oxidation of glucose, an interaction between these products on the one hand and one or more of the acetone bodies on the other." The ketogenic ratio (KR), as proposed by Shaffer (14), is a ratio of the sum of ketogenic factors to the sum of antiketogenic factors: KR $=$ $\mathrm{K} / \mathrm{AK}$. The antiketogenic part of the equation invariably equals 1 so the KRs are always expressed as 2:1, 4:1, etc. For the sake of economy of reading, we leaved out the repeating part not bearing any information and mention only the informative digit.

Shaffer concluded that the maximal ratio compatible with the oxidation of the "ketogenic" molecules becomes possible at the $\mathrm{KR}=1$, making KRs below 1 antiketogenic and KRs above 2 ketogenic. Wilder and Winter (15) described the KR of a food in terms of times the fat content exceeds the amount of carbohydrate and protein combined, roughly. The reasoning was based on their own experimental observation that fats are predominantly ketogenic (90\%), carbohydrates are 
almost $100 \%$ anti-ketogenic, and protein is both ketogenic and antiketogenic, $46-58 \%$ respectively. They arrived, along with Woodyatt and Sansum (13), at the conclusion that KR for induction of ketogenesis should be 2 or higher while the upper limit of antiketogenesis is 1 .

In 1980, Withrow (16) modified the equation and since that time, the equation looked like this:

$\mathrm{KR}=(0.9 \mathrm{~F}+0.46 \mathrm{P}):(\mathrm{C}+0.58 \mathrm{P}+0.1 \mathrm{~F})$ where $\mathrm{F}$ is grams of fat; $\mathrm{P}$ is grams of protein and $\mathrm{C}$ is grams of carbohydrate. Currently, this equation is rarely used in nutrition research and less so in dietetic practice, which is regrettable since properly calculated KRs reveals interesting patterns of diet effects. Previously (9), using the Withrow's equation, we calculated KRs in a number of diets and came to conclusion that the watershed in the group of effects occurs at KR of about 1.7. Above this value, metabolic features of diets were characteristic for ketogenesis, while below this value, they were characteristic for the obesogenic high-fat diet (oHFD), which, in contrast to the diet resulting in ketosis (KD), is high in fat but also in carbohydrates. Here, we analyzed three groups of diets in order to compare our observation regarding the watershed with the classification of diets made by the authors of 62 studies, in which it was possible to calculate KRs.

\section{UNCERTAINTY IN CURRENT DIET LABELLING}

We can see that there is no common criteria in choosing diet compositions for the "normal control" group to start with (Figure 1A). The vast majority of "normal control" diets are clearly anti-ketogenic (KRs below or equal 1). The oHFD group of diets had broader spectrum of KRs ranging from the anti-ketogenic 0.456 to clearly ketogenic 2.994 . The KRs of diets, which were considered ketogenic by the authors, ranged especially broadly: from 0.36 to above 6 . The macronutrient compositions of oHFD diets and KDs overlap although the obesogenic oHFD is discussed in literature as diametrically different from the KD. The metabo- and neuroprotective effects of KD are experimentally and clinically confirmed, however, the low compliance rate of the strict $\mathrm{KD}$ caused mass attempts to reduce the $\mathrm{KR}$ below $\mathrm{KR}=2$, which for a century used to be the minimal accepted value to consider a diet ketogenic.

An example is the Modified Atkins Diet (MAD) first tried at The Johns Hopkins Hospital. It is a protocol replicating the induction phase of the original Atkins diet. MAD is composed of approximately $10 \%$ energy from carbohydrates, $30 \%$ from protein, and $60 \%$ from fat, no calorie restriction (55-58). The MAD became an intervention for treating a number of diseases, first of all in cases of intractable childhood epilepsy but also in pharmacoresistant epilepsy in adults and in pathologies of glucose utilization (58). MAD is labeled "ketogenic" while its $\mathrm{KR}=1.3$ (calculated basing on 11). However, its efficiency is limited: although $70 \%$ of epilepsy patients on MAD experienced a 50\% reduction in seizures, after switching to the strict clinical $\mathrm{KD}(\mathrm{KR}=4)$ the patients benefited from an additional $37 \%$ improvement and $18.5 \%$ became seizure-free $(13,59,60)$ indicating that the KR is indeed an important predictor of diet effectiveness.

\section{EFFECTS OF KD VS. OHFD}

Basing on our review of KR-dependent effects of diets (6), here we compiled a brief overview in order to demonstrate the critical differences between KD and oHFD.

1. The risks of pathologies caused by brain hypometabolism (e.g., due to hypoxia, hypoglycemia, brain trauma) is reduced in diets capable of inducing ketogenesis; the opposite is shown for the oHFD diets (39, 61-69).

2. Inflammation, e.g., neuroinflammation is shown to be induced by oHFD but decreased by KD (70-78) among other things resulting in improved or impaired cognitive function $(76,78-$ $82)$.

3. Neuronal hyperactivity and epilepsy is attenuated by $\mathrm{KD}$ but exacerbated by oHFD $(75,83-85,85-88)$.

4. Inhibition of growth of tumor and metastasis as well as tumor neo-angiogenesis is demonstrated for KD while oHFD increases the risk of cancerogenesis $(8,89-92)$.

5. KD decreased cardiovascular risks while oHFD increases them $(93,94)$.

6. KD lowered the type 2 diabetes risks, improves management of complications and glucose control while oHFD increases the risks, exacerbates complications and induced glucose intolerance (95-99).

\section{BELOW THE KETOGENIC THRESHOLD}

In the ragne of KRs between 1 and 2 lays the area of metabolic uncertainty where the effects are poorly predictable, the definitions are vague and outcomes even more so. The most critical value in this area is 1.5 , the experimentally reached threshold of anti-ketogenesis (100). Here we report the result of our analysis of non-ketogenic diets (Figures 1B,C) using data extracted from the studies:

- Very low carbohydrate diet [VLCD, (51)];

- The Atkins diet - induction and maintaining phases, the Zone diet and very low fat diet, [VLFD, $(52,53)$ ];

- MAD, Zone, Weight Watchers diet (WW) and VLFD (54);

- Ketogenic low carbohydrate diet (KLC) and non-ketogenic low carbohydrate diet (NLC) (25).

The common feature of these diets was that none of them reached the threshold of ketogenesis defined as KR $=1.5$ (100). The diets were roughly isocaloric $(1,412 \pm 35.5 \mathrm{Kcal} /$ day; caloric intake of WW varied averaging 1,400 Kcal), with main outcome a bodymass loss. Beyond the strictly utilitarian standpoint, body-mass loss is an indicator of lipolysis and thus of ketogenesis likelihood.

In diets ranging from $\mathrm{KR}=1.413$ to $\mathrm{KR}=0.06$ (Figure 1B), the metabolic outcome did not depend on KR as directly as it does above the ketogenic threshold (Figure 1C) indicating that mechanisms other than the ketogenesis-glycolysis counterbalancing seem to be predominant. Indeed, in the study of Johnston et al. (25) the inverse relationship has been observed: 

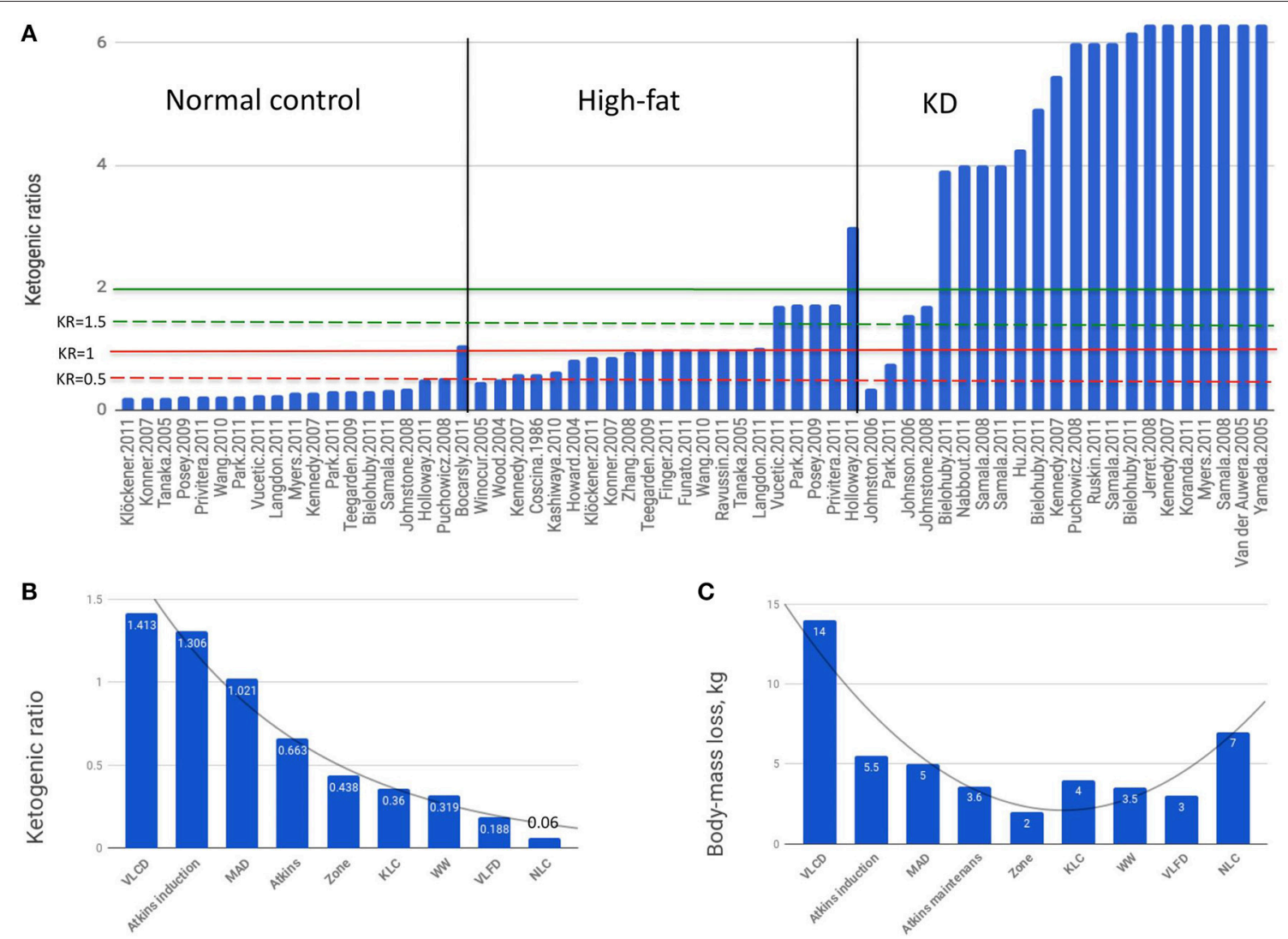

FIGURE 1 | (A) Green line, theoretical threshold of ketogenesis; dashed green line, empirical threshold of ketogenesis. Red line, theoretical threshold of anti-ketogenesis; dashed red line $K R=0.5$. Vertical axis, ketogenic ratios. Horizontal axix, original studies, first author and year (17-50). (B) Ketogenic ratios of diets below the ketogenic threshold. Calculated basing on data extracting from the studies $(25,51-54)$. Gray curves in (B,C) trendlines. (C) Body-mass loss on diets below the ketogenic threshold. VLCD, very low carbohydrate diet; MAD, modified Atkins diet; Zone, the Zone diet; KLC, ketogenic low carbohydrate diet; WW, Weight Watchers diet; VLFD, very low fat diet; NLC, non-ketogenic low carbohydrate diet.

the KLC diet having six times higher KR than NLC (0.35 vs. 0.06) had almost twice lower effect (4 vs. $7 \mathrm{~kg}$ ) leading the authors to conclusion they even used as the article title: "Ketogenic lowcarbohydrate diets have no metabolic advantage over nonketogenic low-carbohydrate diets"-although both diets were undoubtedly anti-ketogenic.

It has been shown before (26) that the prevalence of carbohydrates in an otherwise equally high-protein diets increased energy intake in the ad libitum consumption mode initiating the vicious cycle of non-homeostatic processes, including reward seeking and food addiction (101) and the prevalence of energy-conserving metabolic mode over the homeostatically balanced mode (9). Theoretically, below the $\mathrm{KR}=1.5$, glucocentric metabolic mode prevails while above $\mathrm{KR}=1.5$ the dominant metabolic mode is adipocentric with the important consequence being initiation of lipolysis (102). This is why the body-mass loss of diets is a convenient parameter indirectly indicating that lipolytic processes take place. It has been measured empirically (100) that ketosis is not observed in KRs below 1.5-however, the "ketogenic" label has been assigned to MAD $(\mathrm{KR}=1.021)$ and even to KLC $(\mathrm{KR}=0.36)$.
There is a turning point in the KR-effect interaction curve at $\mathrm{KR}=0.5$ (Figure 1C), the diet nearest to this point being at KR $=0.438$ [the Zone diet, (52-54)]. Further decrease of KRs up to the value of 0.06 resulted in an inverted U-shaped dose-response relationship under the threshold of ketogenesis.

\section{DISCUSSION}

Currently the classification of diets is rather unsatisfactory and diet labels offered by the authors (quite arbitrarily) "normal", "oHFD," or "ketogenic" oftentimes do not correspond to their respective diets' macronutrient compositions. Description based on percentages of energy from each of the macronutrients does not make it easy to qualify diet type and unify the categorization. The macronutrient ratio in terms of ketogenicity is often ignored in qualification of metabolic effects. The most striking example of this is the oHFD diet, which in fact is also high in carbohydrates. As we briefly discussed above, its effects are diametrically opposing those of the ketogenic diet which is also high in fat but low in carbohydrates, resulting in striking differences in diets' physiological effects (see Effects of KD vs. oHFD). 
The ad libitum access to food is the standard protocol in animal experiments although the validity of it is rightfully questioned since the subjects become "sedentary, obese, glucose intolerant, and on a trajectory to premature death" [(103), page 6 ,127]. On the other hand, the low-carbohydrate diets that are high in fat have a number of metabolic advantages: for instance, they facilitate increase energy expenditure by increasing thermogenic effects and excretion of ketone bodies (104).

Greater carbohydrate intake was associated with poorer performance in patients with Alzheimer's disease (105), while KD improved cognition independent of weight loss in healthy human subjects (80). KD improved verbal vocabulary and reaction time in children with epilepsy and attention (4), concentration, and memory in adults with multiple sclerosis (106). Diets limiting carbohydrate intake mimic the effects of fasting or caloric restriction (102). In fact, calorie restriction is not even required on a very low carbohydrate diet to achieve the desired goals, while on a low-fat, high-carbohydrate diet calorie restriction is the principal requirement (107).

The metabolic effects of dietary fat on energy homeostasis differs from the effects of carbohydrates in two key features. One is the ability to store energy in depots - fat is exceptionally

\section{REFERENCES}

1. Seyfried TN. Cancer as a Metabolic Disease: On the Origin, Management, and Prevention of Cancer. Hoboken, NJ: Wiley (2012)

2. Seneff S, Wainwright G, Mascitelli L. Nutrition and Alzheimer's disease: the detrimental role of a high carbohydrate diet. Eur J Intern Med. (2011) 22:134-40. doi: 10.1016/j.ejim.2010.12.017

3. Miranda HV, Outeiro TF. The sour side of neurodegenerative disorders: the effects of protein glycation. J Pathol. (2010) 221:13-25. doi: $10.1002 /$ path. 2682

4. Auburger G, Kurz A. The role of glyoxalases for sugar stress and aging, with relevance for dyskinesia, anxiety, dementia and Parkinson's disease. Aging (2011) 3:5-9. doi: 10.18632/aging.100258

5. Avena NM, Gold MS. Food and addiction - sugars, fats and hedonic overeating. Addiction (2011) 106:1214-5. discussion: 1219-20. doi: 10.1111/j.1360-0443.2011.03373.x

6. Zilberter T, Zilberter Y. Energy metabolism: from neurons and glia to the whole brain: pathology and metabolic correction. Adv Physiol Sci. (2012) 43:37-54.

7. Domouzoglou E, Maratos-Flier E. Fibroblast growth factor 21 is a metabolic regulator that plays a role in the adaptation to ketosis. Am J Clin Nutr. (2011) 93(Suppl.):901S-5S. doi: 10.3945/ajcn.110.001941

8. Klement RJ, Champ CE. Calories, carbohydrates, and cancer therapy with radiation: exploiting the five R's through dietary manipulation. Cancer Metastasis Rev. (2014) 33:217-29. doi: 10.1007/s10555-014-9495-3

9. Zilberter T. Carbohydrate-biased control of energy metabolism: the darker side of the selfish brain. Front Neuroenerget. (2011) 3:8. doi: 10.3389/fnene.2011.00008

10. Bernhard W, Guzmán-Ruiz M, Layritz C, Legutko B, Zinser E, GarcíaCáceres C, et al. (2017). Dietary sugar is critical for high fat diet-induction of hypothalamic inflammation via advanced glycation end-products. $\mathrm{Mol}$ Metab. 6:897-908. doi: 10.1016/j.molmet.2017.06.008

11. Aragno M, Mastrocola R. Dietary sugars and endogenous formation of advanced glycation endproducts: emerging mechanisms of disease. Nutrients (2017) 9:385. doi: 10.3390/nu9040385

12. Gao Y, Bielohuby M, Fleming T, Grabner, GF, Foppen E, Bernhard W, et al. Dietary sugars, not lipids, drive hypothalamic inflammation. Research Gate. (2017) Available Online at: Researchgate https://goo.gl/kNa4wi (Accessed May 15, 2018). good at it, but carbohydrates are limited in this ability. The other is the ability to increase the drive to consume energy. Carbohydrates have a characteristic ability to elicit positive reward and thus addiction $(5,101,108-110)$ while significant carbohydrate restriction in VLCD caused not only energy intake decrease but also energy expenditure increase in both resting and active states (51). In spite of these non-homeostatic features, these mechanisms are evolutionarily appropriate in wild nature, but as soon as the living conditions change the hard-wired pursuit to maximize the energy store becomes a metabolic trap (9s), resulting in non-homeostatic overconsumption and all the negative metabolic consequences it causes.

To conclude, the current classification of diets results in terminological confusion. We suggest that rethinking the existing descriptive approach and reanimating the century-old qualitative and clear-cut criterion may facilitate the use of common language and substantive discussion in nutrition and metabolism.

\section{AUTHOR CONTRIBUTIONS}

$\mathrm{TZ}$ and $\mathrm{YZ}$ equally contributed to the concept, data collection and analysis, writing the manuscript and preparing illustrations.

13. Woodyatt RT. The action of glycol aldehyd and glycerin aldehyd in diabetes mellitus and the nature of antiketogenesis. JAMA (1910) 55:2109-12. doi: 10.1001/jama.1910.04330250005003

14. Shaffer PA Antiketogenesis. I. An in vitro analogy. J BiolChem. (1921) 47: 433-73.

15. Wilder RM, Winter MD. The threshold of ketogenesis. J Biol Chem. (1922) 52:393-401.

16. Withrow CD. The ketogenic diet: mechanism of anticonvulsant action. $A d v$ Neurol. (1980) 7:635-42.

17. Pandit R, De Jong JW, Vanderschuren LJ, Adan RA. Neurobiology of overeating and obesity: the role of melanocortins and beyond. Eur J Pharmacol. (2011) 660:28-42. doi: 10.1016/j.ejphar.2011.01.034

18. Coscina DV, Yehuda S, Dixon LM, Kish SJ, Leprohon-Greenwood CE. Learning is improved by a soybean oil diet in rats. Life Sci. (1986) 38:1789-94. doi: 10.1016/0024-3205(86)90130-X

19. Finger BC, Dinan TG, Cryan JF. High-fat diet selectively protects against the effects of chronic social stress in the mouse. Neuroscience (2011) 192:351-60. doi: 10.1016/j.neuroscience.2011.06.072

20. Funato H, Oda S, Yokofujita J, Igarashi H, Kuroda M. Fasting and high-fat diet alter histone deacetylase expression in the medial hypothalamus. PloS ONE (2011) 6:e18950. doi: 10.1371/journal.pone.0018950

21. Holloway CJ, Cochlin LE, Emmanuel Y, Murray A, Codreanu I, Edwards LM, et al. A high-fat diet impairs cardiac high-energy phosphate metabolism and cognitive function in healthy human subjects. Am J Clin Nutr. (2011) 93:748-55. doi: 10.3945/ajcn.110.002758

22. Howard JK, Cave BJ, Oksanen LJ, Tzameli I, Bjørbæk C, Flier JS. Enhanced leptin sensitivity and attenuation of diet-induced obesity in mice with haploinsufficiency of Socs3. Nat Med. (2004) 10:734-8. doi: 10.1038/ $\mathrm{nm} 1072$

23. Hu XL, Cheng X, Fei J, Xiong ZQ. Neuron-restrictive silencer factor is not required for the antiepileptic effect of the ketogenic diet. Epilepsia (2011) 52:1609-16. doi: 10.1111/j.1528-1167.2011.03171.x

24. Jarrett SG, Milder JB, Liang LP, Patel M. The ketogenic diet increases mitochondrial glutathione levels. J Neurochem. (2008) 106:1044-51. doi: 10.1111/j.1471-4159.2008.05460.x

25. Johnston CS, Tjonn SL, Swan PD, White A, Hutchins H, Sears B. Ketogenic low-carbohydrate diets have no metabolic advantage over nonketogenic low-carbohydrate diets. Am J Clin Nutr. (2006) 83:1055-61. doi: 10.1093/ajcn/83.5.1055 
26. Johnstone AM, Horgan GW, Murison SD, Bremner DM, Lobley GE. Effects of a high-protein ketogenic diet on hunger, appetite, and weight loss in obese men feeding ad libitum. Am J Clin Nutr. (2008) 87:44-55. doi: 10.1093/ajcn/87.1.44

27. Kashiwaya Y, Pawlosky R, Markis W, King MT, Bergman C, Srivastava S, et al. A ketone ester diet increases brain malonyl-CoA and uncoupling proteins 4 and 5 while decreasing food intake in the normal wistar rat. J Biol Chem. (2010) 285:25950-6. doi: 10.1074/jbc.M110.138198

28. Kennedy AR, Pissios P, Otu H, Xue B, Asakura K, Furukawa N, et al. A highfat, ketogenic diet induces a unique metabolic state in mice. Am J Physiol Endocrinol Metab. (2007) 292:E1724-39. doi: 10.1152/ajpendo.00717.2006

29. Klöckener T, Hess S, Belgardt BF, Paeger L, Verhagen LA, Husch A, et al. High-fat feeding promotes obesity via insulin receptor/PI3Kdependent inhibition of SF-1 VMH neurons. Nat Neurosci. (2011) 14:911-8. doi: 10.1038/nn.2847

30. Könner AC, Janoschek R, Plum L, Jordan SD, Rother E, Ma X, et al. Insulin action in AgRP-expressing neurons is required for suppression of hepatic glucose production. Cell Metab. (2007) 5:438-49. doi: 10.1016/j.cmet.2007.05.004

31. Koranda JL, Ruskin DN, Masino SA, Blaise JH. A ketogenic diet reduces long-term potentiation in the dentate gyrus of freely behaving rats. $J$ Neurophysiol. (2011) 106:662-6. doi: 10.1152/jn.00001.2011

32. Langdon KD, Clarke J, Corbett D. Long-term exposure to high fat diet is bad for your brain: exacerbation of focal ischemic brain injury. Neuroscience (2011) 182:82-7. doi: 10.1016/j.neuroscience.2011.03.028

33. Myers TM, Langston JL. Diet composition exacerbates or attenuates soman toxicity in rats: implied metabolic control of nerve agent toxicity. Neurotoxicology (2011) 32:342-9. doi: 10.1016/j.neuro.2011.03.001

34. Nabbout R, Copioli C, Chipaux M, Chemaly N, Desguerre I, Dulac O, et al. Ketogenic diet also benefits Dravet syndrome patients receiving stiripentol: a prospective pilot study. Epilepsia (2011) 52:e54-e69. doi: 10.1111/j.1528-1167.2011.03107.X

35. Park JH, Ahn J, Kim S, Kwon DY, Ha TY. Murine hepatic miRNAs expression and regulation of gene expression in diet-induced obese mice. Mol Cells (2011) 31:33-8. doi: 10.1007/s10059-011-0009-7

36. Park S, Kim DS, Daily JW. Central infusion of ketone bodies modulates body weight and hepatic insulin sensitivity by modifying hypothalamic leptin and insulin signaling pathways in type 2 diabetic rats. Brain Res. (2011) 1401:95-103. doi: 10.1016/j.brainres.2011.05.040

37. Posey KA, Clegg DJ, Printz RL, Byun J, Morton GJ, Vivekanandan-Giri A, et al. Hypothalamic proinflammatory lipid accumulation, inflammation, and insulin resistance in rats fed a high-fat diet. Am J Physiol Endocrinol Metab. (2009) 296:E1003-12. doi: 10.1152/ajpendo.90377.2008

38. Privitera GJ, Zavala AR, Sanabria F, Sotak KL. High fat diet intake during pre and periadolescence impairs learning of a conditioned place preference in adulthood. Behav Brain Funct. (2011) 7:21. doi: 10.1186/1744-9081-7-21

39. Puchowicz MA, Zechel JL, Valerio J, Emancipator DS, Xu K, Pundik S, et al. Neuroprotection in diet-induced ketotic rat brain after focal ischemia. J Cereb Blood Flow Metab. (2008) 28:1907-16. doi: 10.1038/jcbfm.2008.79

40. Ravussin Y, Gutman R, Diano S, Shanabrough M, Borok E, Sarman B, et al. Effects of chronic weight perturbation on energy homeostasis and brain structure in mice. Am J Physiol Regul Integr Comp Physiol. (2011) 300:R1352-62. doi: 10.1152/ajpregu.00429.2010

41. Samala R, Klein J, Borges K. The ketogenic diet changes metabolite levels in hippocampal extracellular fluid. Neurochem Int. (2011) 58:5-8. doi: 10.1016/j.neuint.2010.10.011

42. Samala R, Willis S, Borges K. Anticonvulsant profile of a balanced ketogenic diet in acute mouse seizure models. J Epilepsy Res. (2008) 81:119-27. doi: 10.1016/j.eplepsyres.2008.05.001

43. Tanaka T, Hidaka S, Masuzaki H, Yasue S, Minokoshi Y, Ebihara K, et al. Skeletal muscle AMP-activated protein kinase phosphorylation parallels metabolic phenotype in leptin transgenic mice under dietary modification. Diabetes (2005) 54:2365-74. doi: 10.2337/diabetes.54. 8.2365

44. Teegarden SL, Scott AN, Bale TL. Early life exposure to a high fat diet promotes long-term changes in dietary preferences and central reward signaling. Neuroscience (2009) 162:924-32. doi: 10.1016/j.neuroscience.2009.05.029
45. Van der Auwera I, Wera S, Van Leuven F, Henderson ST. A ketogenic diet reduces amyloid beta 40 and 42 in a mouse model of Alzheimer's disease. Nutr Metab. (2005) 2:28. doi: 10.1186/1743-7075-2-28

46. Vucetic Z, Kimmel J, Reyes TM. Chronic high-fat diet drives postnatal epigenetic regulation of $\mu$-opioid receptor in the brain. Neuropsychopharmacology (2011) 36:1199-206. doi: 10.1038/npp.2011.4

47. Wang C, Bomberg E, Billington CJ, Levine AS, Kotz CM. Brainderived neurotrophic factor (BDNF) in the hypothalamic ventromedial nucleus increases energy expenditure. Brain Res. (2010) 1336:66-77. doi: 10.1016/j.brainres.2010.04.013

48. Winocur G, Greenwood CE. Studies of the effects of high fat diets on cognitive function in a rat model. Neurobiol Aging (2005) 26 (Suppl. 1):46-9. doi: 10.1016/j.neurobiolaging.2005.09.003

49. Wood JD, Nute GR, Richardson RI, Whittington FM, Southwood O, Plastow $\mathrm{G}$, et al. Effects of breed, diet and muscle on fat deposition and eating quality in pigs. Meat Sci. (2004) 67:651-67. doi: 10.1016/j.meatsci.2004.01.007

50. Yamada KA, Rensing N, Thio LL. Ketogenic diet reduces hypoglycemiainduced neuronal death in young rats. Neurosci Lett. (2005) 385:210-4. doi: 10.1016/j.neulet.2005.05.038

51. Ebbeling CB, Swain JF, Feldman HA, Wong WW, Hachey DL, Garcia-Lago $\mathrm{E}$, et al. Effects of dietary composition on energy expenditure during weightloss maintenance. JAMA (2012) 307:2627-34. doi: 10.1001/jama.2012.6607

52. Gardner CD, Kiazand A, Alhassan S, Kim S, Stafford RS, Balise RR et al. Comparison of the Atkins, Zone, Ornish, and LEARN diets for change in weight and related risk factors among overweight premenopausal women: the A To Z Weight Loss Study: a randomized trial. JAMA (2007) 297:969-77. doi: 10.1001/jama.297.9.969

53. Gardner CD, Kim S, Bersamin A, Dopler-Nelson M, Otten J, Oelrich B, et al. Micronutrient quality of weight-loss diets that focus on macronutrients: results from the A TO Z study. Am J Clin Nutr. (2010) 92:304-12. doi: 10.3945/ajcn.2010.29468

54. Dansinger ML, Gleason JA, Griffith JL, Selker HP, Schaefer EJ. Comparison of the Atkins, Ornish, weight watchers, and Zone diets for weight loss and heart disease risk reduction: a randomized trial. JAMA (2005) 293:43-53. doi: 10.1001/jama.293.1.43

55. Kossoff EH, Dorward JL. The modified atkins diet. Epilepsia (2008) 49(Suppl. 8):37-41. doi: 10.1111/j.1528-1167.2008.01831.x

56. Kossoff EH, Bosarge JL, Miranda MJ, Wiemer-Kruel A, Kang HC, Kim HD. Will seizure control improve by switching from the modified Atkins diet to the traditional ketogenic diet. Epilepsia (2010) 51:2496-9. doi: 10.1111/j.1528-1167.2010.02774.x

57. Kossoff EH, Cervenka MC, Henry BJ, Haney CA, Turner Z. A decade of the modified Atkins diet (2003-2013): results, insights, and future directions. Epilepsy Behav. (2013) 29:437-42. doi: 10.1016/j.yebeh.2013.09.032

58. Ito S, Oguni H, Ito Y, Ishigaki K, Ohinata J, Osawa M. Modified Atkins diet therapy for a case with glucose transporter 1 deficiency syndrome. Brain Dev. (2008) 30:226-8. doi: 10.1016/j.braindev.2007.08.006

59. El-Rashidy OF, Nassar MF, Abdel-Hamid IA, Shatla RH, AbdelHamid MH, Gabr SS, et al. Modified Atkins diet vs. classic ketogenic formula in intractable epilepsy. Acta Neurol Scand. (2013) 128, 402-8. doi: 10.1111/ane.12137

60. Ye F, Li XJ, Jiang WL, Sun HB, Liu J. Efficacy of and patient compliance with a ketogenic diet in adults with intractable epilepsy: a meta-analysis. J Neurol. (2015) 11:26-31. doi: 10.3988/jcn.2015.11.1.26

61. Kirsch JR, D’Alecy LG. Hypoxia induced preferential ketone utilization by rat brain slices. Stroke (1984) 15:319-23. doi: 10.1161/01.STR.15.2.319

62. Veech RL, Chance B, Kashiwaya Y, Lardy HA, Cahill GF Jr. (2001) Ketone bodies, potential therapeutic uses. IUBMB Life 51:241-7. doi: 10.1080/152165401753311780

63. Bough KJ, Wetherington J, Hassel B, Pare JF, Gawryluk JW, et al. Mitochondrial biogenesis in the anticonvulsant mechanism of the ketogenic diet. Ann Neurol. (2006) 60:223-35. doi: 10.1002/ana.20899

64. Puchowicz MA, Xu K, Sun X, Ivy A, Emancipator D, Lamanna JC. Diet-induced ketosis increases capillary density without altered blood flow in rat brain. Am J Physiol Endocrinol Metab. (2007) 292:E1607-15. doi: 10.1152/ajpendo.00512.2006

65. Haces ML, Hernandez-Fonseca K, Medina-Campos ON, Montiel T, Pedraza-Chaverri J, Massieu L. Antioxidant capacity contributes 
to protection of ketone bodies against oxidative damage induced during hypoglycemic conditions. Exp Neurol. (2008) 211: 85-96. doi: 10.1016/j.expneurol.2007.12.029

66. Schutz PW, Wong PK, O’Kusky J, Innis SM, Stockler S. Effects of d-3hydroxybutyrate treatment on hypoglycemic coma in rat pups. Exp Neurol. (2011) 227:180-7. doi: 10.1016/j.expneurol.2010.10.013

67. Kim do Y, Vallejo J, Rho JM. Ketones prevent synaptic dysfunction induced by mitochondrial respiratory complex inhibitors. J Neurochem. (2010) 114:130-41. doi: 10.1111/j.1471-4159.2010.06728.x

68. Barks JD, Liu Y, Shangguan Y, Djuric Z, Ren J, Silverstein FS. Maternal high-fat diet influences outcomes after neonatal hypoxic-ischemic brain injury in rodents. J Cereb Blood Flow Metab. (2016) 37:307-18. doi: 10.1177/0271678X15624934

69. Goldbart AD, Row BW, Kheirandish-Gozal L, Cheng Y, Brittian KR, Gozal D. High fat/refined carbohydrate diet enhances the susceptibility to spatial learning deficits in rats exposed to intermittent hypoxia. Brain Res. (2006) 1090:190-6. doi: 10.1016/j.brainres.2006.03.046

70. Vanitallie TB, Nonas C, Di Rocco A, Boyar K, Hyams K, Heymsfield SB. Treatment of Parkinson disease with diet-induced hyperketonemia: a feasibility study. Neurology (2005) 64:728-30. doi: 10.1212/01.WNL.0000152046.11390.45

71. Murphy P, Likhodii S, Nylen K, Burnham WM. The antidepressant properties of the ketogenic diet. Biol Psychiatry (2004) 56:981-3. doi: 10.1016/j.biopsych.2004.09.019

72. Murphy P, Likhodii SS, Hatamian M, McIntyre Burnham W. Effect of the ketogenic diet on the activity level of Wistar rats. Pediatr Res. (2005) 57:353-7. doi: 10.1203/01.PDR.0000150804.18038.79

73. Henderson ST, Vogel JL, Barr LJ, Garvin F, Jones JJ, Costantini LC. Study of the ketogenic agent AC-1202 in mild to moderate Alzheimer's disease: a randomized, double-blind, placebo-controlled, multicenter trial. Nutr Metab. (2009) 6:31. doi: 10.1186/1743-7075-6-31

74. de Lau LM, Bornebroek M, Witteman JC, Hofman A, Koudstaal PJ, Breteler MM. Dietary fatty acids and the risk of Parkinson disease: the Rotterdam study. Neurology (2005) 64:2040-5. doi: 10.1212/01.WNL.0000166038.67153.9F

75. Maalouf M, Rho JM. Oxidative impairment of hippocampal long-term potentiation involves activation of protein phosphatase $2 \mathrm{~A}$ and is prevented by ketone bodies. J Neurosci Res. (2008) 86:3322-30. doi: 10.1002/jnr. 21782

76. Page KA, Williamson A, Yu N, McNay EC, Dzuira J, McCrimmon RJ, et al. Medium chain fatty acids improve cognitive function in intensively treated type 1 diabetic patients and support in vitro synaptic transmission during acute hypoglycemia. Diabetes (2009) 58:1237-44. doi: 10.2337/db08-1557

77. White H, Venkatesh B. Clinical review: ketones and brain injury. Crit Care (2011) 15:219. doi: 10.1186/cc10020

78. Maalouf M, Rho JM, Mattson MP. The neuroprotective properties of calorie restriction, the ketogenic diet, and ketone bodies. Brain Res Rev. (2009) 59:293-315. doi: 10.1016/j.brainresrev.2008.09.002

79. Krikorian R, Shidler MD, Dangelo K, Couch SC, Benoit SC, Cleggc DJ. Dietary ketosis enhances memory in mild cognitive impairment. Neurobiol Aging (2012) 33:425.e19-e27. doi: 10.1016/j.neurobiolaging.2010.10.006

80. Iacovides S, Meiring RM. The effect of a ketogenic diet versus a high-carbohydrate, low-fat diet on sleep, cognition, thyroid function, and cardiovascular health independent of weight loss: study protocol for a randomized controlled trial. Trials (2018) 19:62. doi: 10.1186/s13063-018-2462-5

81. McPherson PA, McEneny J. The biochemistry of ketogenesis and its role in weight management, neurological disease and oxidative stress. J Physiol Biochem. (2011) 68:141-51. doi: 10.1007/s13105-011-0112-4

82. Miller VJ, Villamena FA, Volek JS. Nutritional ketosis and mitohormesis: potential implications for mitochondrial function and human health. J Clin Nutr Metab. (2018) 2018:5157645. doi: 10.1155/2018/5157645

83. Huttenlocher PR. Ketonemia and seizures: metabolic and anticonvulsant effects of two ketogenic diets in childhood epilepsy. Pediatr Res. (1976) 10:536-40. doi: 10.1203/00006450-197605000-00006

84. Newman JC, Kroll F, Ulrich S, Palop JJ, Verdin E. Ketogenic diet or BHB improves epileptiform spikes, memory, survival in Alzheimer's model. bioRxiv (2017) 136226:1-30. doi: 10.1101/136226
85. Bostock E, Kirkby KC, Taylor BV. The current status of the ketogenic diet in psychiatry. Front Psychiatry (2017) 8:43. doi: 10.3389/fpsyt.2017.00043

86. Bough KJ. Rho JM. Anticonvulsant mechanisms of the ketogenic diet. Epilepsia (2007) 48:43-58. doi: 10.1111/j.1528-1167.2007.00915.x

87. Samokhina E, Popova I, Malkov A, Ivanov AI, Papadia D, Osypov A, et al. Chronic inhibition of brain glycolysis initiates epileptogenesis. J Neurosci Res. (2017) 95:2195-206. doi: 10.1002/jnr.24019

88. Zilberter Y, Zilberter M. The vicious circle of hypometabolism in neurodegenerative diseases: ways and mechanisms of metabolic correction. $J$ Neurosci Res. (2017) 95:2217-35. doi: 10.1002/jnr.24064

89. Bozzetti F, Zupec-Kania B. Toward a cancer-specific diet. Clin Nutr. (2015) 35:1188-95 doi: 10.1016/j.clnu.2015.01.013

90. Haller S, Jasper H. You are what you eat: linking high-fat diet to stem cell dysfunction and tumorigenesis. Cell Stem Cell (2016) 18:564-6. doi: 10.1016/j.stem.2016.04.010

91. Kwon OJ, Zhang B, Zhang L, Xin L. High fat diet promotes prostatic basalto-luminal differentiation and accelerates initiation of prostate epithelial hyperplasia originated from basal cells. Stem Cell Res. (2016) 16:682-91. doi: 10.1016/j.scr.2016.04.009

92. Chen GL, Luo Y, Eriksson D, Meng X, Qian C, Bäuerle T, et al. High fat diet increases melanoma cell growth in the bone marrow by inducing osteopontin and interleukin 6. Differentiation (2016) 24:1-17 doi: 10.18632/oncotarget.8474

93. Labbe DP, Zadra G, Yang M, Lin CY, Reyes JM, Cacciatore S, et al. High fat diet accelerates MYC-driven prostate cancer through metabolic and epigenomic rewiring. Cancer Res. (2016) 76(Suppl. 14):2674. doi: 10.1158/1538-7445.AM2016-2674

94. Brehm BJ, Seeley RJ, Daniels SR, D’alessio DA. A randomized trial comparing a very low carbohydrate diet and a calorie-restricted low fat diet on body weight and cardiovascular risk factors in healthy women. J Clin Endocrinol Metab. (2003) 88, 1617-23. doi: 10.1210/jc.2002-021480

95. Jeon BT, Jeong EA, Shin HJ, Lee Y, Lee DH, Kim HJ, et al. (2012). Resveratrol attenuates obesity-associated peripheral and central inflammation and improves memory deficit in mice fed a high-fat diet. Diabetes 61:1444-54. doi: $10.2337 / \mathrm{db} 11-1498$

96. Yancy WS, Foy M, Chalecki AM, Vernon MC, Westman EC. A lowcarbohydrate, ketogenic diet to treat type 2 diabetes. Nutr Metab. (2005) 2:34. doi: 10.1186/1743-7075-2-34

97. Nielsen JV, Joensson EA. Low-carbohydrate diet in type 2 diabetes: stable improvement of bodyweight and glycemic control during 44 months followup. Nutr Metab. (2008) 5:14. doi: 10.1186/1743-7075-5-14

98. Basu S, Yoffe P, Hills N, Lustig RH. The relationship of sugar to populationlevel diabetes prevalence: an econometric analysis of repeated cross-sectional data. PloS ONE (2013) 8:e57873. doi: 10.1371/journal.pone.0057873

99. Abudushalamu Y, Visnagri A, Viswambharan H, Bonthron D, Kearney M, Asipu A. P24 sucrose-and high fat-induced insulin resistance leads to endothelial dysfunction and is associated with ketohexokinase activation. Heart (2016) 102:A9. doi: 10.1136/heartjnl-2016-310696.28

100. Talbot FB, Metkalf KM, Moriarty ME. Epilepsy: chemical investigations of rational treatment by production of ketosis. Am J Dis Child. (1927) 33:218-25. doi: 10.1001/archpedi.1927.04130140038005

101. Berthoud HR, Lenard NR, Shin AC. Food reward, hyperphagia, and obesity. Am J Physiol Regul Integr Comp Physiol. (2011) 300:R1266-77 doi: 10.1152/ajpregu.00028.2011

102. Westman EC, Mavropoulos J, Yancy WS, Volek JS. A review of lowcarbohydrate ketogenic diets. Curr Atheroscler Rep. (2003) 5:476-83. doi: 10.1007/s11883-003-0038-6

103. Martin B, Ji S, Maudsley S, Mattson MP. "Control" laboratory rodents are metabolically morbid: why it matters. Proc Natl Acad Sci USA. (2010) 107:6127-33. doi: 10.1073/pnas.0912955107

104. Noakes TD, Windt J. Evidence that supports the prescription of lowcarbohydrate high-fat diets: a narrative review. Br J Sports Med. (2017) 51:133-9. doi: 10.1136/bjsports-2016-096491

105. Gardener SL, Rainey-Smith SR, Sohrabi HR, Weinborn M, Verdile G, Fernando WMAD, et al. Increased carbohydrate intake is associated with poorer performance in verbal memory and attention in an APOE genotype-dependent manner. J Alzheimers Dis. (2017) 58:193-201. doi: 10.3233/JAD-161158 
106. Francis HM, Stevenson RJ. Potential for diet to prevent and remediate cognitive deficits in neurological disorders. Nutr Rev. (2018) 76:204-17. doi: 10.1093/nutrit/nux073

107. Bueno NB, de Melo ISV, de Oliveira SL, da Rocha Ataide T. Very-lowcarbohydrate ketogenic diet v. low-fat diet for long-term weight loss: a meta-analysis of randomised controlled trials. Br J Nutr. (2013) 110:1178-87. doi: $10.1017 /$ S0007114513000548

108. Wojnicki FH, Charny G, Corwin RL. Binge-type behavior in rats consuming trans-fat-free shortening. Physiol Behav. (2008) 94:627-9. doi: 10.1016/j.physbeh.2008.03.016

109. Pickering C, Alsio J, Hulting AL, Schioth HB. Withdrawal from freechoice high-fat high-sugar diet induces craving only in obesity-prone animals. Psychopharmacology (2009) 204:431-43. doi: 10.1007/s00213-0091474-y
110. Zilberter T. Food addiction and obesity: do macronutrients matter? Front Neuroenerg. (2012) 4:7. doi: 10.3389/fnene.2012.00007

Conflict of Interest Statement: The authors declare that the research was conducted in the absence of any commercial or financial relationships that could be construed as a potential conflict of interest.

Copyright (c) 2018 Zilberter and Zilberter. This is an open-access article distributed under the terms of the Creative Commons Attribution License (CC BY). The use, distribution or reproduction in other forums is permitted, provided the original author(s) and the copyright owner(s) are credited and that the original publication in this journal is cited, in accordance with accepted academic practice. No use, distribution or reproduction is permitted which does not comply with these terms. 